\title{
Survival of Cercospora sojina on Soybean Leaf Debris in Illinois
}

\author{
Guirong Zhang and Carl A. Bradley, Department of Crop Sciences, University of Illinois, Urbana 61801
}

Accepted 10 May 2014. Published 23 July 2014.

\section{ABSTRACT}

Zhang, G., and Bradley, C. A. 2014. Survival of Cercospora sojina on soybean leaf debris in Illinois. Plant Health Progress doi:10.1094/PHP-RS-140005 .

Historically, frogeye leaf spot (FLS, caused by Cercospora sojina) of soybean has been observed more frequently in the southern United States than the north-central United States. However, in recent years, FLS field observations have increased in the north-central United States. To better understand the survival rate of $C$. sojina in Illinois, a field study was conducted at three locations: Monmouth (west-central Illinois), Urbana (east-central Illinois), and Dixon Springs (southeastern Illinois). At each location, soybean leaves affected by FLS were placed at depths of 0,10 , and $20 \mathrm{~cm}$ and retrieved at different durations up to 24 months. To determine the viability of $C$. sojina in the collected leaves, a greenhouse bioassay was used. Survival of $C$. sojina declined equally with time at all three locations through 19 months. After 24 months, C. sojina from leaves that had been placed at Monmouth and Urbana were no longer viable, whereas leaves that had been placed at Dixon Springs produced viable inoculum. Depth of leaf placement had no effect on survival of $C$. sojina at any of the locations. These results suggest that planting a nonhost crop for two years in central Illinois will reduce levels of $C$. sojina inoculum to a negligible amount; however, soybean farmers in southern Illinois may need a longer rotation for FLS management.

\section{INTRODUCTION}

Frogeye leaf spot (FLS), caused by Cercospora sojina, is one of the most important foliar diseases of soybean (Glycine max). This disease is especially severe in the warm, humid areas of the world $(2,14,15)$. In the United States, the disease has been identified as far north as Wisconsin (11), and has been reported to cause yield losses in Canada (17). Soybean yield losses due to FLS primarily occur because of a reduction in photosynthetic area and premature defoliation (1). The estimated annual soybean yield reductions caused by FLS in the United States ranged between 19,568 and 345,148 metric tons from 1996 to 2009 $(8,16)$. In experimental research plots, yield reductions caused by FLS ranged from $17 \%$ to $21 \%$ in Indiana (9) and from $0 \%$ to $31 \%$ in southeastern states (12).

Historically, FLS has caused greater soybean yield suppression in the southern United States compared to the north-central United States; however, the impact of FLS on soybean yields in the north central United States has increased since 2001 (16). In Illinois, FLS can occur across the entire state (5), but little is known about how well $C$. sojina survives in soybean debris over time, in different areas of the state, or how burying leaf debris infected by $C$. sojina will affect its survival. Achieving a better understanding of $C$. sojina survival and management of FLS with cultural practices such as crop rotation and tillage has become more important in light of the recent discovery of $C$. sojina isolates with resistance to quinone outside inhibitor fungicides in the United States (18). The objective of this study was to evaluate the survival rate of $C$. sojina in affected soybean leaf debris at different regions of Illinois, when buried at three depths over a two-year period.

Corresponding author: Carl A. Bradley. Email: carlbrad@illinois.edu

\section{SOYBEAN LEAF COLLECTION AND PLACEMENT IN FIELD TRIALS}

Soybean leaves uniformly and severely affected by FLS symptoms (approximately 50\% disease severity) were collected from a soybean field growing in Pope County, Illinois, in September 2008. Leaves were stored loosely in sealed plastic bags in a walk-in cold room (approximately $4^{\circ} \mathrm{C}$ ) for approximately 1.5 months. Ten leaflets were placed in nylon bags and were then placed in protective fiberglass mesh sacks (approximately $15 \mathrm{~cm}^{2}$ ). The fiberglass mesh sacks were made by cutting fiberglass window screen into squares and then stapling two squares together (one on top of the other). In November 2008, the sacks were placed on the soil surface or buried in the soil at depths of 10 and $20 \mathrm{~cm}$ in fields at University of Illinois research farms located near Urbana, Monmouth, and Dixon Springs, Illinois (Fig. 1). Sacks were attached by wire to metal fence posts ( $1.5 \mathrm{~m}$ long) that were driven into the soil to mark the areas where sacks were buried and to hold the sacks on top of the soil in place. Soil characters, latitude and longitude of the three locations are listed in Table 1. Temperature sensors (WatchDog, Spectrum Technologies, Inc. Plainfield, IL) were placed at the three depths to record temperature hourly. Enough of the sacks were used to allow for four different collection timings with 4 replicates for each collection timing $\times$ depth combination for each location. Precipitation data were collected from weather stations located at the research farms. Sacks were retrieved from Monmouth and Dixon Springs at 7, 12, 19, and 24 months after placement, but due to a collection error, samples at Urbana were collected at 12, 19, and 24 months only. After retrieving the leaves from the sacks, they were air dried at room temperature for at least 5 days, ground to a fine powder with a mortar and pestle and placed in a sterile plastic vial to be used to inoculate soybean leaves in the greenhouse. 


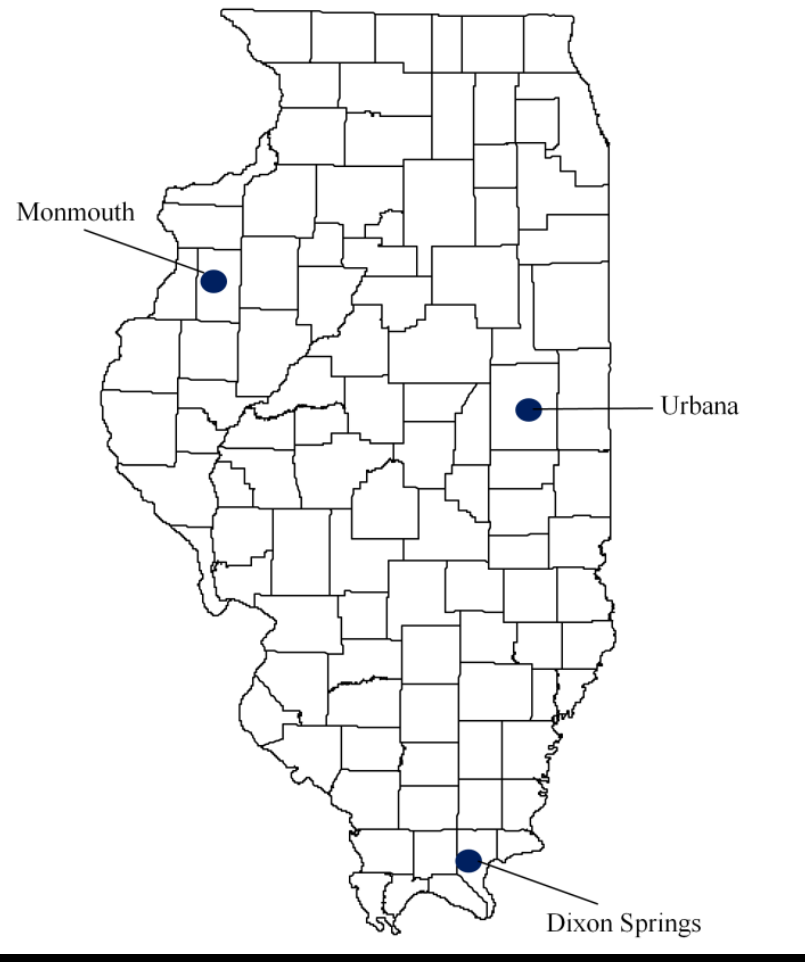

FIGURE 1

Locations in Illinois where Cercospora sojina infected leaf debris were evaluated for $C$. sojina survival over time.

\section{BIOASSAY TO DETERMINE VIABILITY OF CERCOSPORA SOJINA}

The viability of $C$. sojina was tested on the leaves of the susceptible soybean cultivar 'Asgrow 3101' in an air-conditioned greenhouse room using a bioassay method similar to what was used by Khan et al. (6), in which they inoculated sugar beet plants with ground leaves that were infected by $C$. beticola. Soybean plants were grown in trays $(26 \times 53 \times 6 \mathrm{~cm})$ with 24 individual pots $(8 \times 6 \times 6 \mathrm{~cm})$ that contained potting mix (Sunshine Mix 1, Sun Gro Horticulture Inc., Bellevue, WA). Before inoculation, soybean plants were watered until the potting mix was saturated, and wet paper towels were placed on the soil surface between plants to maintain high relative humidity $(\mathrm{RH})$. Ten-day-old soybean seedlings with completely unrolled leaves at the unifoliolate node (V1 stage) (4) were inoculated with the previously prepared ground diseased soybean leaves. The abaxial surface of unifoliolate leaves was sprayed with $0.005 \%$ Tween 20 (Sigma-Aldrich, St. Louis, MO) until leaves were wet, then $0.05 \mathrm{~g}$ of inoculum was placed on one abaxial leaf surface for each treatment. The control treatments included inoculation with sterilized ground soybean leaves and a noninoculated control. All treatments were arranged in one tray as a completely randomized design. The inoculated plants were then covered with transparent plastic domes $(15 \times 53 \times 28 \mathrm{~cm})$ and incubated for 6 days to maintain high relative humidity $(\geq 90 \%)$. After 6 days, the plastic domes were removed, and after maintaining the plants for 15 days, the number of lesions per leaf was counted. The temperature of the potting mixture surface was $25 \pm 2^{\circ} \mathrm{C}$ without the plastic domes and $23 \pm 2{ }^{\circ} \mathrm{C}$ with the plastic domes. Supplemental lighting was used (1,000 watt, high pressure sodium lights) with a photoperiod of 14 hours. Plants were watered daily as needed from the bottom, so that splashing did not occur. Because of limited space, inoculations of all the collected samples from different locations and times were assayed over multiple trials; therefore, inoculation with $1 \times 10^{4}$ conidial suspension of $C$. sojina (isolate $\mathrm{S7}$ ) (13) on the leaves in every trial was used as an internal control to ensure that conditions were optimal for infection and FLS symptom development.

\section{STATISTICAL ANALYSIS}

Due to missing data from the 7 month collection time from the Urbana location, only data from the 12,19 , and 24 month collection times were used for data analyses that compared locations, collection times, and burial depths. Levene's test for variance homogeneity of $C$. sojina conidia-inoculated control trials indicated that trial variances were not significantly different from another $(P>0.05)$; therefore, data from all trials were combined for further analysis. Analysis of variance (ANOVA) was conducted using the general linear model procedure (PROC GLM) in SAS (version 9.2, SAS Institute Inc., Cary, NC) to determine the effects of the fixed nested three factors (time, location, and depth) on the viability of $C$. sojina. All factors were fixed and depth was nested in locations. When $F$ was significant $(P \leq 0.05)$, Fisher's protected least significant difference (LSD) at $\alpha=0.05$ was calculated to compare differences in mean number of lesions per leaf that were produced from leaves buried at different depths over time at different locations. Furthermore, linear regression analysis was performed to predict inoculum viability, combining the three depths with time using the mathematical equation $\mathrm{y}=\mathrm{aX}+\mathrm{b}$, in which $\mathrm{y}=$ predicted log transformation lesion number per leaflet, $b=$ number of lesions produced at the beginning of the experiment (or viability calculated at time zero), and $\mathrm{a}=$ rate of viability decline at time $\mathrm{X}$. For regression analysis, data were transformed for normality, and data from the 7-month collection time were included for Dixon Springs and Monmouth.

\section{SURVIVAL OF CERCOSORA SOJINA IN SOYBEAN LEAVES}

Location and sampling time had a significant $(P<0.0001)$ effect on survival of $C$. sojina, but depth did not. No interactive effects were significant; therefore, only main effects are presented. The greatest number of FLS lesions was observed on

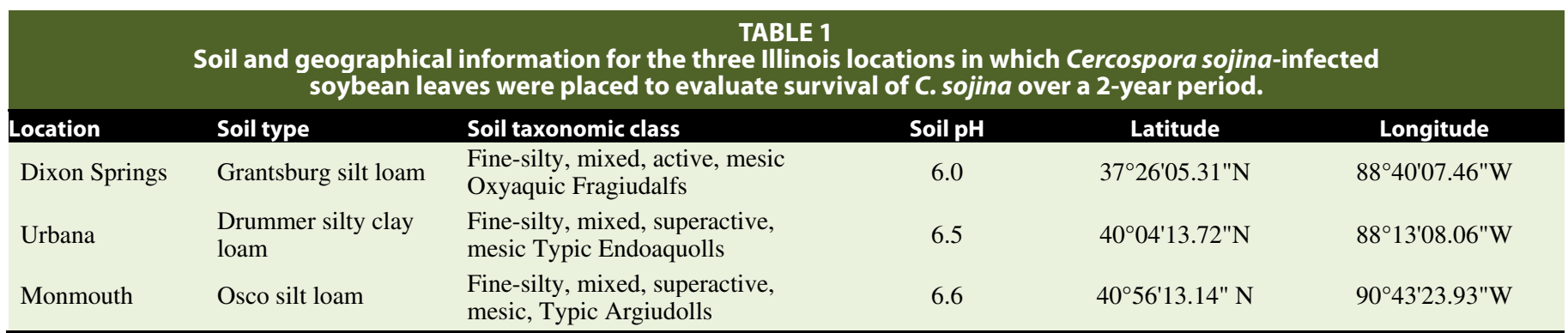


greenhouse plants when inoculated with leaf debris collected from Dixon Springs, which was significantly greater than the number of FLS lesions caused by leaf debris collected from Urbana and Monmouth (Table 2). The greatest number of FLS lesions occurred when inoculated with leaf debris collected after 12 or 19 months, compared to leaf debris collected after 24 months (Table 3).

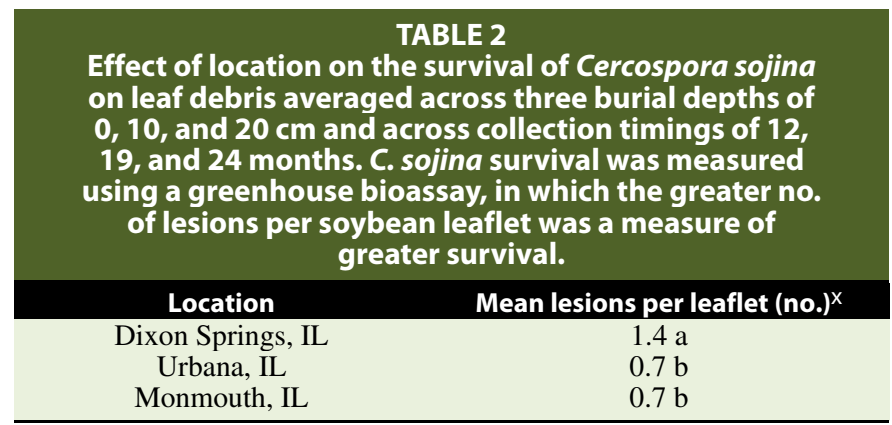

${ }^{x}$ Means followed by the same letter are not significantly different according to Fisher's protected least significant difference test $(\alpha=0.05)$.

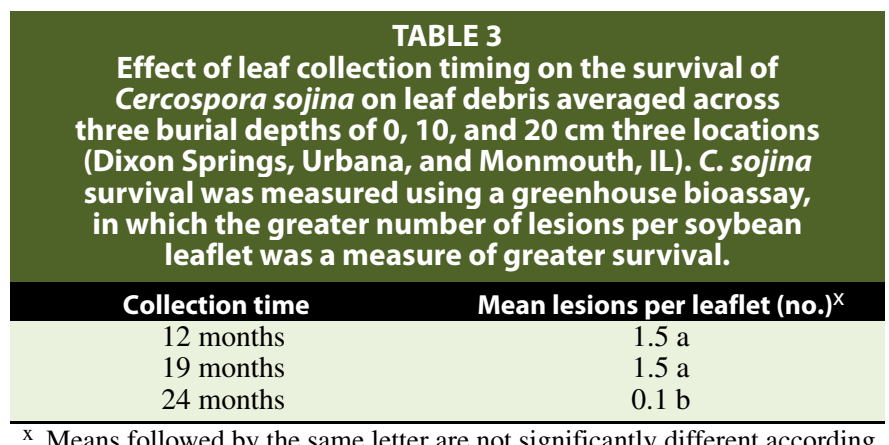

${ }^{x}$ Means followed by the same letter are not significantly different according to Fisher's protected least significant difference test $(\alpha=0.05)$.
When combined across different burial depths, regression analysis results indicate that the rate of survival (as measured by number of lesions) decreased at similar rates (rate $=0.03$ to 0.04 ) for all three locations (Fig. 2). The coefficients of determinations were relatively high for each location, indicating that the linear regression models fit the data relatively well. The models that fit the data the best were from Dixon Springs and Monmouth $\left(R^{2}=\right.$ 0.72 and 0.70 , respectively), while the model for Urbana had a slightly lower coefficient of determination $\left(R^{2}=0.52\right)$.

No matter the soil depth measured, the temperature at Dixon Springs was always higher than temperatures at Urbana or Monmouth (Table 4). The overall average temperature differences between Dixon Springs and Urbana were $2.5^{\circ} \mathrm{C}, 3.3^{\circ} \mathrm{C}$, and $3.3^{\circ} \mathrm{C}$ for the soil surface, $10-\mathrm{cm}$ depth, and $20-\mathrm{cm}$ depth, respectively. The overall average temperature differences between Dixon Springs and Monmouth were $3.9^{\circ} \mathrm{C}, 3.4^{\circ} \mathrm{C}$, and $4.3^{\circ} \mathrm{C}$ for the soil surface, $10-\mathrm{cm}$ depth, and $20-\mathrm{cm}$ depth, respectively. Total rainfall was greatest at Monmouth $(2,673 \mathrm{~mm})$, lowest at Urbana (1,529 $\mathrm{mm})$, and intermediate at Dixon Springs (2,457 mm) (Table 5).

\section{DISCUSSION AND CONCLUSIONS}

In this study, $C$. sojina inoculum in soybean leaf debris was viable up to 24 months after overwintering at the three different locations in Illinois, which is the longest field survival period reported for this pathogen in the north-central United States. Cruz and Dorrance (3) reported that $C$. sojina survived in soybean debris on the soil surface for 7 months at two locations in Ohio, and $\mathrm{Ma}$ and $\mathrm{Li}$ (10) reported that $C$. sojina could survive for up to 12 months in China. In a study designed similarly to the one conducted in Illinois, Khan et al. (6) evaluated survival of a similar fungus, $C$. beticola, in North Dakota and reported that $C$. beticola survived up to 22 months on sugar beet leaves. In light of the results from our study, soybean growers in Illinois should consider rotating to a nonhost crop for two seasons after a severe outbreak of FLS to minimize the amount of viable inoculum that

\begin{tabular}{|c|c|c|c|c|c|c|c|c|c|c|}
\hline \multirow[b]{3}{*}{ Year } & \multirow{2}{*}{\multicolumn{4}{|c|}{$\begin{array}{l}\text { Average monthly temperature measured at the } \\
\text { three locations in Illinois in which Cercospc } \\
\text { Dixon Springs soil temperature }\left({ }^{\circ} \mathrm{C}\right)\end{array}$}} & \multirow{2}{*}{\multicolumn{3}{|c|}{$\begin{array}{l}\text { TABLE } 4 \\
\text { surface }(0 \mathrm{~cm}) \text {, at a } 10-\mathrm{cm} \text { dep } \\
\text { sojina survival on soybean leaf } \\
\text { Urbana soil temperature }\left({ }^{\circ} \mathrm{C}\right)\end{array}$}} & \multirow{2}{*}{\multicolumn{3}{|c|}{ Monmouth soil temperature $\left({ }^{\circ} \mathrm{C}\right)$}} \\
\hline & & & & & & & & & & \\
\hline & Month & $0 \mathrm{~cm}$ & $10 \mathrm{~cm}$ & $20 \mathrm{~cm}$ & $0 \mathrm{~cm}$ & $10 \mathrm{~cm}$ & $20 \mathrm{~cm}$ & $0 \mathrm{~cm}$ & \multirow{2}{*}{$\begin{array}{c}10 \mathbf{~ c m} \\
0.2\end{array}$} & $20 \mathrm{~cm}$ \\
\hline 2008 & Dec & 1.9 & 4.0 & 5.9 & -3.1 & 0.3 & 1.1 & -5.8 & & 0.7 \\
\hline \multirow[t]{12}{*}{2009} & Jan & -1.1 & 1.9 & 3.8 & -7.0 & -1.1 & -0.2 & -9.7 & -3.0 & -1.6 \\
\hline & Feb & 3.5 & 3.3 & 4.4 & -0.5 & 0.2 & 0.2 & -1.8 & -0.7 & -0.7 \\
\hline & Mar & 9.9 & 10.0 & 10.7 & 6.4 & 5.0 & 7.2 & 3.7 & 4.1 & 3.4 \\
\hline & Apr & 13.7 & 13.6 & 14.4 & 10.7 & 9.1 & 11.2 & 9.4 & 9.6 & 8.6 \\
\hline & May & 18.3 & 21.0 & 21.1 & 17.2 & 16.6 & 18.4 & 16.0 & 18.0 & 16.1 \\
\hline & Jun & 23.9 & 26.6 & 26.1 & 22.8 & 23.9 & 24.4 & 21.5 & 23.9 & 22.2 \\
\hline & Jul & 22.4 & 26.3 & 25.9 & 20.9 & 22.3 & 22.6 & 20.3 & 24.2 & 22.6 \\
\hline & Aug & 23.0 & 26.5 & 26.3 & 20.8 & 21.1 & 22.2 & 20.6 & 24.0 & 23.1 \\
\hline & Sep & 20.9 & 24.0 & 24.0 & 19.2 & 19.8 & 21.3 & 17.7 & 20.8 & 19.6 \\
\hline & Oct & 12.0 & 15.3 & 16.6 & 9.8 & 12.3 & 12.6 & 8.6 & 11.0 & 12.0 \\
\hline & Nov & 10.2 & 11.1 & 12.9 & 7.3 & 8.3 & 9.0 & 7.3 & 7.9 & 8.7 \\
\hline & Dec & 1.5 & 3.8 & 6.2 & -2.0 & 0.6 & 1.6 & -3.9 & 0.0 & 1.4 \\
\hline \multirow[t]{12}{*}{2010} & Jan & -1.9 & 1.9 & 4.0 & -6.6 & -1.1 & 1.1 & -9.1 & -1.9 & -0.8 \\
\hline & Feb & -0.3 & 2.4 & 4.0 & -4.3 & -0.9 & -0.2 & -7.5 & -1.7 & -1.0 \\
\hline & Mar & 8.6 & 8.7 & 9.6 & 6.2 & 5.4 & 0.1 & 4.9 & 3.9 & 3.3 \\
\hline & $\mathrm{Apr}$ & 15.9 & 16.7 & 15.1 & 14.7 & 13.7 & 14.8 & 14.2 & 14.3 & 12.6 \\
\hline & May & 19.5 & 22.3 & 21.8 & 18.3 & 17.3 & 18.7 & 17.0 & 17.4 & 16.1 \\
\hline & Jun & 25.5 & 28.4 & 23.8 & 23.7 & 24.8 & 25.3 & 23.2 & 24.6 & 23.8 \\
\hline & Jul & 26.3 & 29.4 & 28.1 & 24.7 & 25.3 & 21.8 & 24.3 & 25.5 & 25.6 \\
\hline & Aug & 26.4 & 29.4 & 27.9 & 24.4 & 25.2 & 23.9 & 23.6 & 27.8 & 25.1 \\
\hline & Sep & 21.0 & 22.8 & 22.8 & 19.4 & 20.9 & 22.4 & 18.2 & 21.2 & 20.1 \\
\hline & Oct & 14.8 & 16.5 & 17.0 & 13.9 & 16.7 & 15.8 & 12.5 & 15.1 & 14.0 \\
\hline & Nov & 8.3 & 8.8 & 11.0 & 6.0 & 10.3 & 9.4 & 5.1 & 7.1 & 6.7 \\
\hline & Average & 13.5 & 15.6 & 16.0 & 11.0 & 12.3 & 12.7 & 9.6 & 12.2 & 11.7 \\
\hline
\end{tabular}




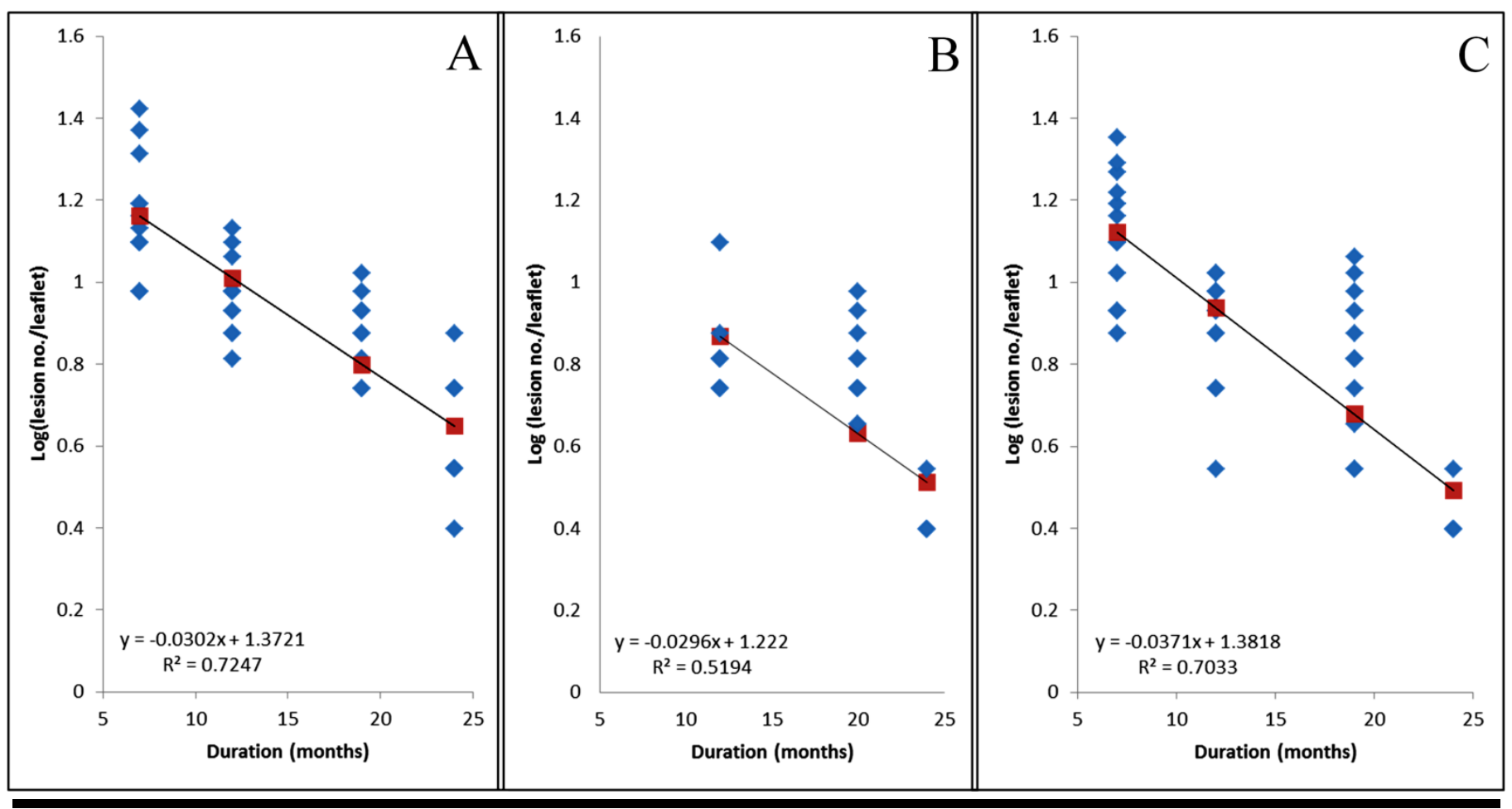

FIGURE 2

Relationships between Cercospora sojina survival (as measured by the Log of frogeye leaf spot lesion no. per soybean leaflet attained from a greenhouse bioassay) and time at (A) Dixon Springs, (B) Urbana, and (C) Monmouth, Illinois.

might be present in soybean debris. Furthermore, the greatest reduction in $C$. sojina viability was found between the 19 - and 24-month collection periods. This 19-month collection period would be the approximate time that $C$. sojina conidia would be present, splashing onto leaves, and causing infections in the second season.

The greatest survival of $C$. sojina was at the Dixon Springs location in southeastern Illinois. The Dixon Springs location had the warmest temperatures compared to the other locations. Of two counties in Ohio, more $C$. sojina conidia were obtained from the leaf debris that had overwintered in the most southern county (Clark) compared to a more northern county (Wayne) after 7 months (3). Better survival of $C$. sojina in more southerly climates could attribute to the greater yield losses observed historically in the southern United States compared to the northcentral United States (16). Warmer temperatures in the southern United States and southern areas of Illinois likely provide a better climate for $C$. sojina survival and increase the risk of FLS damage in those areas. Based on these findings, soybean growers in southern Illinois should be more aware of the threat of FLS and should use preventative tactics to manage FLS, such as planting resistant cultivars.

In this study, burial depth of leaf debris had no effect on $C$. sojina survival. Burying affected soybean debris with tillage has been recommended as a potential FLS management tactic (14). In light of these findings, burying the soybean debris will not affect survival of $C$. sojina; however, it may reduce the impact of C. sojina inoculum from affected debris since conidia that are buried would not be able to splash onto soybean leaves and cause infections. The results of this trial are different from those reported by Khan et al. (6), in which survival of $C$. beticola was greatest in sugar beet leaf debris left on the soil surface compared to debris that was buried 10 or $20 \mathrm{~cm}$.
Kim et al. (7) suggested that sexual reproduction likely was occurring among $C$. sojina populations in Arkansas, and Zhang et al. (18) reported that isolates of $C$. sojina in Tennessee were resistant to quinone outside inhibitor fungicides. The implications of $C$. sojina's survival in soybean debris in Illinois across multiple years on sexual reproduction and fungicide resistance is not known at this time, but survival of $C$. sojina may contribute to sexual reproduction and to the selection of fungicide resistant isolates in Illinois. If overwintering populations of $C$. sojina are causing FLS in Illinois, then these populations may be more likely to be exposed to repeated fungicide applications, which may lead to selection of fungicide resistant isolates. In light of C. sojina survival in a north-central state such as Illinois, its potential sexual reproduction, and presence of fungicide-resistant isolates in the United States, continued monitoring of FLS distribution and severity in Illinois and other north-central states should occur to determine if FLS is becoming more prominent in this soybean production region.

\section{ACKNOWLEDGMENTS}

The authors thank the Illinois Soybean Association for providing funding for G. Zhang's graduate research assistantship. The authors also thank E. Adee, K. Ames, S. Ebelhar, D. Pedersen, S. Thomas, and J. Weems for technical assistance.

\section{LITERATURE CITED}

1. Akem, C. N., and Dashiell, K. E. 1994. Effect of planting date on severity of frogeye leaf spot and grain yield of soybean. Crop Prot. 13:607-610.

2. Akem, C. N., Dashiell, K. E., and Uwala, A. C. 1992. Prevalence of frogeye leaf spot of soybean in Nigeria. Int. J. Trop. Plant Dis. 10:181183.

3. Cruz, C. D., and Dorrance, A. E. 2009. Characterization and survival of Cercospora sojina in Ohio. Plant Health Progress doi:10.1094/PHP-20090512-03-RS. 
4. Fehr, W. R., Caviness, C. E., Burmood, D. T., and Pennington, J. S. 1971. Stage of development descriptions for soybeans, Glycine max (L.) Merrill. Crop Sci. 11:929-931.

5. Hobbs, H. A., Herman, T. K., Slaminko, T. L, Wang, Y., Nguyen, B. T., McCoppin, N. K., Domier, L. L., and Hartman, G. L. 2010. Occurrences of soybean viruses, fungal diseases, and pests in Illinois soybean rust sentinel plots. Plant Health Progress doi:10.1094/PHP-2010-0827-01-BR.

6. Khan, J., del Rio, L. E., Nelson, R., Rivera-Varas, V., Secor, G. A., and Khan, M. F. R. 2008. Survival, dispersal, and primary infection site for Cercospora beticola in sugar beet. Plant Dis. 92:741-745.

7. Kim, H., Newell, A. D., Cota-Sieckmeyer, R. G., Rupe, J. C., Fakhoury, A. M., and Bluhm, B. H. 2013. Mating-type distribution and genetic diversity of Cercospora sojina populations on soybean from Arkansas: Evidence for potential sexual reproduction. Phytopathology 103:10451051.

8. Koenning, S. R., and Wrather, J. A. 2010. Suppression of soybean yield potential in the continental United States by plant diseases from 2006 to 2009. Plant Health Progress doi:10.1094/PHP-2010-1122-01-RS.

9. Laviolette, F. A., Athow, K. L., Probst, A. H., Wilcox, J. R., and Abney, T. S. 1970. Effect of bacterial pustule and frogeye leaf spot on yield of Clark soybean. Crop Sci. 10:418-419.

10. Ma, S. M., and Li, B. 1987. Cercospora sojina overwinter test. Soybean Sci. 25:29-34.

11. Mengistu, A., Kurtzweil, N. C., and Grau, C. R. 2002. First report of frogeye leaf spot (Cercospora sojina) in Wisconsin. Plant Dis. 86:1272.
12. Mian, M. A. R., Boerma, H. R., Phillips, D. V., Kenty, M. M., Shannon, G., Shipe, E. R., Soffes Blount, A. R., and Weaver, D. B. 1998. Performance of frogeye leaf spot-resistant and -susceptible near-isolines of soybean. Plant Dis. 82:1017-1021.

13. Mian, M. A. R., Missaoui, A. M., Walker, D. R., Phillips, D. V., and Boerma, H. R. 2008. Frogeye leaf spot of soybean: a review and proposed race designations for isolates of Cercospora sojina Hara. Crop Sci. 48:1424.

14. Phillips, D. V. 1999. Frogeye leaf spot. Pages 20-21 in: Compendium of Soybean Diseases. 4th ed. G. L. Hartman, J. B. Sinclair, and J. C. Rupe, eds. American Phytopathological Society, St. Paul, MN.

15. Ploper, L. D., González, V., Gálvez, M. R., Devani, M. R., Ledesma, F., and Zamorano, M. A. 2001. Frogeye leaf spot of soybean caused by Cercospora sojina in northern Argentina. Plant Dis. 85:801.

16. Wrather, J. A., and Koenning, S. R. 2009. Effects of diseases on soybean yields in the United States 1996 to 2007. Plant Health Progress doi:10.1094/PHP-2009-0401-01-RS.

17. Wrather, A., Shannon, G., Balardin, R., Carregal, L., Escobar, R., Gupta, G. K., Ma, Z., Morel, W., Ploper, D., and Tenuta, A. 2010. Effect of diseases on soybean yield in the top eight producing countries in 2006. Online. Plant Health Progress doi:10.1094/PHP-2010-0125-01-RS.

18. Zhang, G. R., Newman, M. A., and Bradley, C. A. 2012. First report of the soybean frogeye leaf spot fungus (Cercospora sojina) resistant to quinone outside inhibitor fungicides in North America. Plant Dis. 96:767. 